\title{
Screening mungbean [Vigna radiata (L.) wilczek] genotypes for mungbean yellow mosaic virus resistance under natural condition
}

\begin{abstract}
Mungbean Yellow Mosaic Virus (MYMV), transmitted through the white fly (Bemisia tabaci) in the persistent manner is one of the most pernicious diseases of Vigna species. Twenty-five genotypes of mungbean [Vigna radiata (L.) Wilczek] were sown in randomized block design with two replications during the summer season in 2015. The test entries were evaluated against the mungbean yellow mosaic virus $(M Y M V)$ under natural field conditions. Screening for $M Y M V$ resistance was done by planting infector rows along with the test entries. Percent Disease Incidence (PDI) was calculated. The differential response against $M Y M V$ observed and the results revealed that most of the genotypes studied were characterized as moderately susceptible to highly susceptible. In spite of the variable response to $M Y M V$, IPM 02-03, KM 2241, PDM 139, Pusa 0672, HUM 16, ML 1464 and TARM-1 of the mungbean genotypes exhibited resistance during the summer, 2015. The present investigation suggests that these genotypes could possibly be utilized as donors to develop $M Y M V$ resistant lines $M Y M V$ resistance by introgressing in agriculturally important but $M Y M V$ susceptible genotypes. Consequently, in the near future, the improved varieties may surfeit the sustainable agriculture production in the biotic stress prone areas.
\end{abstract}

Keywords: genotype, mungbean, screening, yellow mosaic virus, percent disease incidence
Volume 7 Issue 6 - 2017

\author{
A Nishant Bhanu, MN Singh, K Srivastava \\ Department of Genetics and Plant Breeding, Institute of \\ Agricultural Sciences
}

Correspondence: A Nishant Bhanu, Department of Genetics and Plant Breeding, Institute of Agricultural Sciences, Banaras Hindu University, Varanasi- 22I 005, India, Email nishant.bhanu@gmail.com

Received: July 22, 2017| Published: November 09, 2017

\section{Introduction}

Legumes are vital, environment-friendly food grain crops with a rich source of proteins, minerals and vitamins besides carbohydrates. They are next to cereals in terms of their nutritive and economic value. In addition, they play a pivotal role in the restoration of soil fertility by atmospheric nitrogen fixation through symbiosis with Rhizobium species, and also play an important part in the sustainability of agricultural production system. Besides this, characteristics like rapid growth, early maturity and easily digestibility without flatulence further add to their value in various cropping systems. ${ }^{1}$ Per contra, the total production and productivity of legumes are affected by a number of biotic (viral, fungal, bacterial pathogens and insects) and abiotic (temperature, drought, salinity, water logging etc.) stresses. ${ }^{2}$ Among the biotic factors, Mungbean yellow mosaic virus (MYMV) is one of the most destructive and devastating diseases that limits the mungbean production throughout Asia, including India. ${ }^{3,4}$

The virus is a member of the Gemini viridae family, belonging to the Begomovirus genus with bipartite genome, ${ }^{5}$ and is transmitted by the insect vector, white fly (Bemisia tabaci) in a persistent (calculative) manner., ${ }^{3,6}$ The early symptoms of the virus become evident with the development of yellow specks along the veins which progressively spreads and turns the entire leaf yellow. In the severe cases, the entire leaf may become chlorotic which later turns in to necrotic regions. ${ }^{7}$ The affected plants flower sparsely and the pods formed are curled with reduced size and increased percent of the shrivelled seeds. ${ }^{3,8}$ The yield loss from the viral diseases in pulses accounts upto 80 percent, while the $M Y M V$ alone causes losses upto 80 to 100 percent in mungbean. ${ }^{9}$ Management of this disease is only possible by the way of reducing the vector viz., white fly population using insecticides which are ineffective under severe infestations making a complete destruction of the virus knotty. Therefore, development and use of the virus resistant cultivars turn out to be the most effective and economical strategy against $M Y M V .{ }^{10}$ Keeping this background information into consideration, the present investigation was envisaged with the objective to identify the mungbean resistant genotypes against $M Y M V$ based on the field screening to evaluate its expediency in breeding for $M Y M V$ resistance.

\section{Materials and methods}

A total of 25 diverse genotypes of mungbean [Vigna radiata (L.) Wilczek] were obtained from Department of Genetics and Plant Breeding, Institute of Agricultural Sciences, BHU, Varanasi, India for the screening of mungbean yellow mosaic disease under natural conditions. The investigation was carried out at the Agriculture Research Farm of Institute of Agricultural Sciences, Banaras Hindu University, Varanasi, India which is located in the South-Eastern part of Varanasi city at 25' 18 " N latitude, 83'03" E longitude. The field screening trials were laid in randomized block design with two replications during the summer season of 2015. Each plot consisted of a single row of three-meter length with $30 \mathrm{~cm}$ and $10 \mathrm{~cm}$ row to row and plant to plant spacing, respectively. The infector row method was adopted in which one-row infector line of Co 5 (urdbean) was raised after every two-test entries to evaluate $M Y M V$ infection. Disease scoring was done on the basis of the visual symptoms. Plants were randomly selected and their leaves showing clear symptoms (veinal yellowing and scattered bright yellow spots) and total leaves were counted and percent disease incidence was calculated by using the formula given by Wheeler. ${ }^{11}$ The disease was scored on 0-5 arbitrary scale, as suggested by Bashir ${ }^{12}$ and Akhtar et al., ${ }^{13}$ and the genotypes were scored as Highly resistant (HR), Resistant (R), Moderately Resistant (MR), Susceptible (S) and Highly Susceptible (HS) based on disease severity (Table 1). 
Percent incidence $(P I)=\frac{\text { Total number of infected leaves }}{\text { Total number of leaves observed }} \times 100$
Percent incidence index $(P D I)=\frac{\text { Sum of numarical rating }}{\text { Total number of leaves observed } \times \text { Max.grade }} \times 100$

\section{Results and discussion}

Legume viruses consisting of both RNA and DNA viruses infect legumes severely, thus have been a major threat to the production of several crops e.g. mungbean, urdbean, cowpea etc. In mungbean, Mungbean Yellow Mosaic Virus (MYMV), which is a DNA begomovirus is the most severe one due to its persistent nature of transmission. In addition, the rapid development of the viral recombinant strains and the presence of wide host range for the vector Bemesia tabaci possess a serious constraint to the mungbean production in India. Akhtar et al., ${ }^{14}$ reported that identification of the resistance source is the most reliable and economical method for the management of this virus as no virucide is available for the management of $M Y M V$ disease. Even though several genotypes and varieties have been identified showing resistance against $M Y M V$, lack of durable resistance has been observed in most of the cases. Continuous screening during the year is required for the identification of the resistance source against MYMV.

Consequently, screening for identification of $M Y M V$ resistance source in the mungbean germplasm has been performed by a number of the scientists, ${ }^{15-17}$ but with a little success. In the present study, the difference in the level of resistance shown by different mungbean genotypes based on the visual symptoms in response to $M Y M V$ infection was studied for all the 25 mungbean genotypes, and percent disease incidence was worked out. Due to the planting of the most susceptible check Co 5 (urdbean) after every two test entries and due to a good build-up of the white fly population (5-10 whiteflies plant-1) there were good chances of the spread of disease minimizing the chances of disease escape. At the end of the experiment, all the check lines turned completely yellow, showing maximum disease severity, ensuring a good evaluation of mungbean germplasm against the yellow mosaic disease.

On the basis of percent disease index recorded, the mungbean genotypes were classified into six groups (Table 1). The percent disease incidence varied from 4.45 to 70.35 percent in summer, 2015 .
Out of the 25 mungbean genotypes, 7 genotypes viz. IPM-02-03, Pusa 0672, ML 1464, KM 2241, PDM-139, TARM-1, and HUM 16 were found to be resistant (Table 2). Three genotypes i.e., ML 1465, IPM 02-17, and ML 1296 were categorized as moderately resistant. Three genotypes namely, HUM 1, HUM 7, and ML 717 were categorised under moderately susceptible. Similarly, susceptible and highly susceptible consisted of 3 (ML 712, Pusa 95-31, and AKM 9904) and 9 (HUM 12, LG 460, K 851, Pusa Vishal, COGG 902, MH 841, SML 1455, China mung and Kopergaon) genotypes, respectively (Table 2). It is evident from the results that only 7 genotypes out of the 25 appeared as resistant in mungbean, which indicated the existence of small amount of resistance in genotypes against $M Y M V$. None of the genotypes was highly resistant, showing the uniform prevalence of disease in the field. The results of the present screening were in close agreement with the previous findings. Shad et al., ${ }^{18}$ found no immunity or resistance in 254 lines; all lines were susceptible to highly susceptible to the virus.

Among the 146 lines screened, only one line was found to be resistant to the virus, which showed that this virus is a severe problem. ${ }^{13}$ The resistance nature of the genotypes IPM-02-03, PDM139, Pusa 0672, and HUM 16 have also been reported by several scientists. ${ }^{19-23}$ However, in a recent report where 63 mungbean entries were evaluated under the natural conditions, ten entries viz., KMP-13, $19,20,22,23,24,40,45$, MLGG-8 and WGG-42 have been found immune to mungbean yellow mosaic virus disease. ${ }^{24}$ On the other hand, in evaluation of 106 genotypes of mungbean none of the genotypes showed highly resistant and resistant reaction ${ }^{25}$ which suggests that great variation in genotype response to $M Y M V$ represents variability in their genetic makeup.

The absence of the highly resistant lines from the test germplasm population of mungbean highlights the need for extensive work for exploring new sources of germplasm collection. Lack of resistant varieties necessitates the development of virus resistant varieties through inter-specific hybridization and biotechnology in the future. However, critical investigations like forced feeding method, agro inoculation method, etc., are necessary to ascertain the resistance level in these germplasm lines. Indirect selection of using molecular markers linked to $M Y M V$ resistant genes would facilitate precision plant breeding and the high-throughput marker-assisted selection (MAS) of the resistant genotypes.

Table I Disease scoring scale (0-5) for MYMV based on the percentage of disease incidence (PDI)

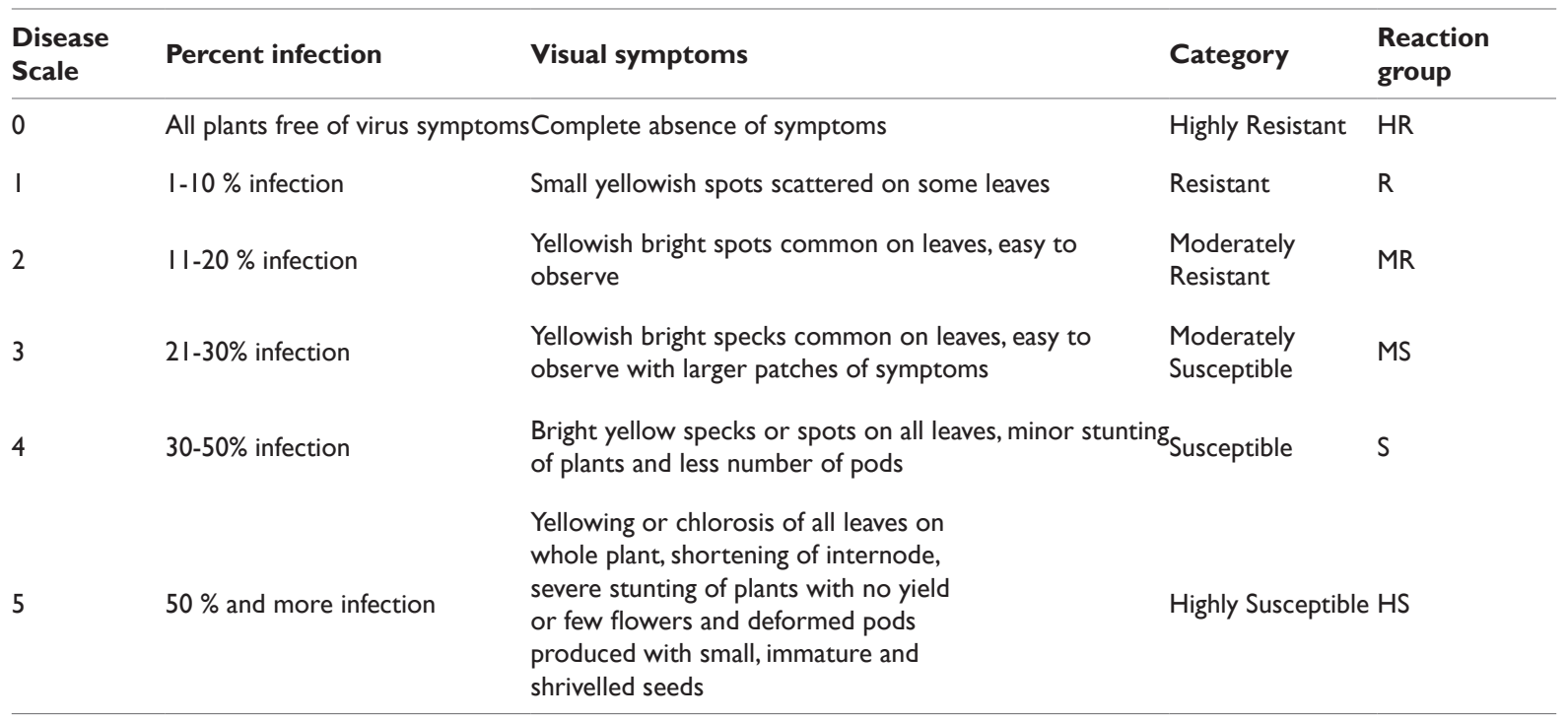


Table 2 Reaction of mungbean genotypes against MYMV in agricultura research station, $\mathrm{BHU}$, Varanasi during the summer, 2015

\begin{tabular}{|c|c|c|c|c|}
\hline S. No. & Genotypes & $\begin{array}{l}\text { Percentage } \\
\text { of disease } \\
\text { incidence }\end{array}$ & $\begin{array}{l}\text { Disease } \\
\text { scale }\end{array}$ & $\begin{array}{l}\text { Disease } \\
\text { reaction }\end{array}$ \\
\hline $\mathrm{I}$. & IPM-02-03 & 4.25 & I & $\mathrm{R}$ \\
\hline 2. & Pusa 0672 & 4.45 & I & $\mathrm{R}$ \\
\hline 3. & ML I464 & 5.1 & I & $\mathrm{R}$ \\
\hline 4. & KM 224I & 5.35 & I & $\mathrm{R}$ \\
\hline 5. & PDM-I39 & 5.85 & I & $\mathrm{R}$ \\
\hline 6. & TARM-I & 6.6 & I & $\mathrm{R}$ \\
\hline 7. & HUM 16 & 7.8 & I & $\mathrm{R}$ \\
\hline 8. & ML I465 & 11.34 & 2 & MR \\
\hline 9. & IPM 02-I7 & 12.8 & 2 & MR \\
\hline 10. & ML 1296 & 14.76 & 2 & MR \\
\hline II. & HUM I & 26.45 & 3 & MS \\
\hline 12. & HUM 7 & 27.3 & 3 & MS \\
\hline 13. & ML 7I7 & 27.64 & 3 & MS \\
\hline 14. & ML 7I2 & 37.86 & 4 & $\mathrm{~S}$ \\
\hline 15. & Pusa 95-3I & 38.65 & 4 & $\mathrm{~S}$ \\
\hline 16. & AKM 9904 & 47.27 & 4 & $\mathrm{~S}$ \\
\hline 17. & HUM I2 & 53.35 & 5 & $\mathrm{HS}$ \\
\hline 18. & LG 460 & 58.75 & 5 & $\mathrm{HS}$ \\
\hline 19. & K $85 \mathrm{I}$ & 61.4 & 5 & $\mathrm{HS}$ \\
\hline 20. & Pusa Vishal & 62.55 & 5 & $\mathrm{HS}$ \\
\hline 21. & COGG 902 & 63.2 & 5 & $\mathrm{HS}$ \\
\hline 22. & MH 84-I & 63.55 & 5 & $\mathrm{HS}$ \\
\hline 23. & SML I 455 & 64.55 & 5 & $\mathrm{HS}$ \\
\hline 24. & China mung & 66.7 & 5 & $\mathrm{HS}$ \\
\hline 25. & Kopergaon & 70.35 & 5 & $\mathrm{HS}$ \\
\hline 26. & Co $5^{*}$ & 75.5 & 5 & $\mathrm{HS}$ \\
\hline
\end{tabular}

*Co 5 genotype of urdbean was used as the infector row.

\section{Acknowledgements}

None.

\section{Conflict of interest}

The author declares no conflict of interest.

\section{References}

1.K aramany EL. Double purpose (forage and seed) of mung bean production 1-effect of plant density and forage cutting date on forage and seed yields of mung bean (Vigna radiata (L.) Wilczck). Res J Agril Biol Sci. 2006;2:162-165.

2. Sahoo L, Sugla T, Jaiwal PK. In vitro regeneration and genetic transformation of Vignaspecies. In: Jaiwal PK, et al. editors. Biotechnology for the improvement of legumes. Kluwer, Dordrecht, Netherlands; 2002. p. 1-48.
3. Nariani TK. Yellow mosaic of Mung (Phaseolus aureus L.). Indian Phytopath. 1960;13(1):24-29.

4. Nene YL. Viral diseases of some warm weather pulse crops in India. Plant Dis Rep. 1973;57(5):463-467.

5. Karthikeyan AS, Vanitharani R, Balaji V, et al. Analysis of an isolate of Mungbean yellow mosaic virus (MYMV) with a highly variable DNA B component. Arch of Virol. 2004;149(8):1643-1652.

6. Nene YL. A survey of viral diseases of pulse crops in Uttar Pradesh. A survey of viral diseases of pulse crops in Uttar Pradesh. 1972;87:1-191.

7. Qazi J, Ilyas M, Mansoor, S, et al. Legume yellow mosaic viruses: genetically isolated begomoviruses. Mol Plant Path. 2007;8(4):343-348.

8. Nene YL. Diseases of soybean and their control. Indian Farming 1969;19:19-20.

9. Naimuddin. Major viral diseases of pulses and their management. India: Ind Inst of Pulses Res Kanpur; 2001. p. 1-22.

10. Karthikeyan A, Sudha M, Senthil N, et al. Screening and identification of random amplified polymorphic DNA (RAPD) markers linked to mungbean yellow mosaic virus (MYMV) resistance in mungbean (Vignaradiata (L.) Wilczek). Arch of Phytopath and Plant Protec. 2012;45(6):712-716

11. Wheeler BEJ. An introduction to plant diseases. London: John Wiley and Sons Ltd; 1969. p. 9-374.

12. Bashir M. Studies on viral diseases of major pulse crops and identification of resistant sources. Technical Annual Report (April, 2004 to June, 2005) of ALP Project. Nat Agri. Res Centre, Islamabad: Crop Sciences Institute; 2005. p. 1-169.

13. Akhtar KP, Dickinson M, Hodgetts J, et al. The phytoplasma disease 'mung bean phyllody' is now present in Pakistan. Plant Path. 2010;59(2):399-399.

14. Akhtar KP, Sarwar G, Abbas G, et al. Screening of mungbean germplasm against mungbean yellow mosaic India virus and its vector Bemisia tabaci. Crop protection. 2011;30(9):1202-1209.

15. Akhtar KP, Ahsanul H. Standardization of a graft inoculation method for the screening of mungbean germplasm against Mungbean yellow mosaic virus (MYMV). The Plant Path J. 2003;19(5):257-259.

16. Bashir M. Studies on viral disease of major pulse crops: Identification of resistant sources. Ann Tech Rep PARC for 2003-2004; 2003. p. 1-76.

17. Bashir M, Jamali AR, Ahmad Z. Genetic resistance in mungbean and mashbean germplasm against mungbean yellow mosiac begomovirus. Mycopath. 2006;4(2):1-4.

18. Shad N, Mughal SM, Farooq K, et al. Evaluation of mungbean germplasm for resistance against mungbean yellow mosaic begomovirus. Pak J Bot 2006;38(2):449-457.

19. Asthana AN. Pulse crops research in India. Indian J Agril Sci. 1998;68(8):448-452.

20. Datta S, Gangwar S, Kumar S, et al. Genetic diversity in selected Indian Mungbean [Vigna radiata (L.) Wilczek] cultivars using RAPD Markers American J Plant Sci. 2012;3(8):1085-1091.

21. Paul PC, Biswas MK, Mandal D, et al. Studies on host resistance of Mungbean against Mungbean Yellow Mosaic Virus in the agroecological condition of lateritic zone of West Bengal. The Bioscan . 2013;8(2):583-887.

22. Mohan S, Sheeba A, Murugan E, et al. Screening of mungbean germplasm for resistance to Mungbean Yellow Mosaic Virus under natural condition. Ind J of Sci and Tech. 2014;7(7):891-896. 
23. Subedi S, Neupane S, Ghimire TN. Screening of mungbean and black gram genotypes as sources of genetic resistance against Mungbean Yellow Mosaic Disease. Nep J Agril Sci. 2016;14:148-155.

24. Bhaskar AV. Genotypes against major diseases in green gram and black gram under natural field conditions. Int J Curr Microbiol App Sci. 2017;6(6):832-843.
25. Deepa H, Govindappa MR, Kenganal M, et al. Screening of greengram genotypes against mungbean yellow mosaic virus diseases under field condition. Int J Pure App Biosci. 2017;5(2):1049-1056. 